Research Journal of Environmental and Earth Sciences10(1): 16-23, 2018

DOI:10.19026/rjees.10.5854

ISSN: 2041-0484; e-ISSN: 2041-0492

(C) 2018 Maxwell Scientific Publication Corp.

Submitted: October 10, $2017 \quad$ Accepted: January 19, 2018

Published: May 20, 2018

\title{
Research Article \\ Assessment of Groundwater Pollution with Heavy Metals at the Al-Akaider Landfill Area, North Jordan
}

\author{
Ibrahim Ahmad Ali BanyYaseen and TareqAwad Al-Naeem \\ Institute of Earth and Environmental Sciences, Al al-Bayt University, Mafraq, Jordan
}

\begin{abstract}
In order to assess the potential pollution of the groundwater around Al-akaider landfill waste area, heavy metals $(\mathrm{Zn}, \mathrm{Cu}, \mathrm{Mn}, \mathrm{Pb}, \mathrm{Cd}, \mathrm{Fe})$ used concentrations in the water well samples around thestudyarea. The sources of groundwater pollution from natural sources are related to the rock formation or anthropogenic sources, including the direct application of fertilizers and pesticides, or irrigation through the use of wastewater treatment plant and human consumption activity. Twenty-one groundwater samples were collected from the surrounding of the Alakaiderlandfill area, which is a part of the Yarmouk Basin. The Feed wells in the area were discharged from the shallow aquifer of Wadi Es-Sir formation (A7) and Amman silicified formation (B2). The groundwater level is 220 $\mathrm{m}$ below the surface and the groundwater movement northeast towards the west (through under the landfill area). The samples were analyzed by Atomic Absorption Spectrometer (AAS) to determine their heavy metal concentration for $\mathrm{Zn}, \mathrm{Cu}, \mathrm{Mn}, \mathrm{Pb}, \mathrm{Cd}$ and $\mathrm{Fe}$. The results of the analysis showed that the concentrations of $\mathrm{Zn}, \mathrm{Cu}$, $\mathrm{Mn}, \mathrm{Pb}$ and $\mathrm{Cd}$ in all samples are within the maximum permissible limits of the Jordanian Institution for Standards and Metrology Jordan Drinking Water. The iron concentration of well T10 is higher than the allowable limit for the Jordanian Institution for Standards and Metrology of drinking water (JISM, 2008). This well (T10) is located $4 \mathrm{~km}$ away from the west landfill area and the contamination in this well is an indication of natural sources, which mixes deep water with deep aquifer.
\end{abstract}

Keywords: Al-akaiderlandfill, groundwater, heavy metal, jordan, pollution

\section{INTRODUCTION}

The surface water (fresh water, lakes, rivers and streams) and groundwater (borehole water and springs) are the principal natural water resources. Pollution of groundwater is one of the most important environmental issues affecting water contamination (Vodelaet al., 1997; Öztürket al., 2009). Heavy metals are among the major pollutants of water sources (Marcovecchioet al.,2007). Despite this, heavy metals are sensitive indicators for monitoring changes in the marine environment. Due to human industrial activities, the levels of heavy metals in the aquatic environment are seriously increasing and have created a major global concern (Khodabakhshiet al., 2001; Ghasemiet al., 2011). Some of these metals are essential for the growth, development and health of living organisms. Whereas the non-essential, are indestructible and most of them are categorized as toxic species to living organisms (Underwood, 1956). However, the toxicity of metals depends on their concentration levels in the environment. With increasing concentrations in the environment and a decrease in the capacity of the soils to retain the heavy metals, they leach into the groundwater and the soil solution. Thus, these toxic metals can be accumulated in living tissues and concentrate through the food chain.

The pollution of heavy metals is a global issue because these metals have toxic effects on living organisms at a high concentration (Forstner, 1990; Harte et al., 1991; Schuurmann and Market, 1998; MacFarlane and Burchett, 2000; Ghrefat and Yusuf, 2006). In addition, heavy metals are of high ecological significance because they have not been removed from water by self-purification methods, but they tend to accumulate in reservoirs and enter the food chain. The increase of heavy metal levels in a reservoir is shown to be mainly due to the presence of their concentrations in the bottom sediment (Ghrefat and Yusuf, 2006). The occurrence of heavy metals in the environmental pollution, resulting from anthropogenic activities and natural processes such as chemical weathering of rocks and volcanic activities, play a role in enriching the water of the reservoirs with heavy metals.

Jordan is a prime country to examine due to its even more direlack offresh water resources, as

\footnotetext{
Corresponding Author: Ibrahim Ahmad Ali BanyYaseen, Institute of Earth and Environmental Sciences, Al al-Bayt University, Mafraq, Jordan

This work is licensed under a Creative Commons Attribution 4.0 International License (URL: http://creativecommons.org/licenses/by/4.0/).
} 
compared with its regional neighbors, who are more blessed with water or have the wealth to create it with desalination technology. Jordan is considered as the third driest country in the world, which is not surprising due to the desert environment that encompasses $92 \%$ of its land area (Denny et al., 2008). Its per capita share of renewable water resources is just $140 \mathrm{~m}^{3}$ per year, which is expected to fall to $90 \mathrm{~m}^{3}$ per year by the year 2025 (Nortcliffet al., 2008).

Treated/untreated wastewater is another major source of groundwater pollution, indicating the presence of bacteriological contamination in the wells surrounding ArRamtha wastewater treatment plant. The rock/soil-water interaction plays an important role in the modification of the groundwater chemistry, especially water hardness (Obeidatet al., 2008; AbuJaber and Kharabsheh, 2008).

The main objective of this study is to assess the potential pollution due to the presence of heavy metals in the groundwater around Al-akaider landfill waste area. Also, to measure the heavy metals $(\mathrm{Zn}, \mathrm{Cu}, \mathrm{Mn}$, $\mathrm{Pb}, \mathrm{Cd}$ and $\mathrm{Fe}$ ) concentrations and $\mathrm{PH}$, TDS and $\mathrm{EC}$ of the water well samples around thearea. Access to the main sources of groundwater pollution such as from the

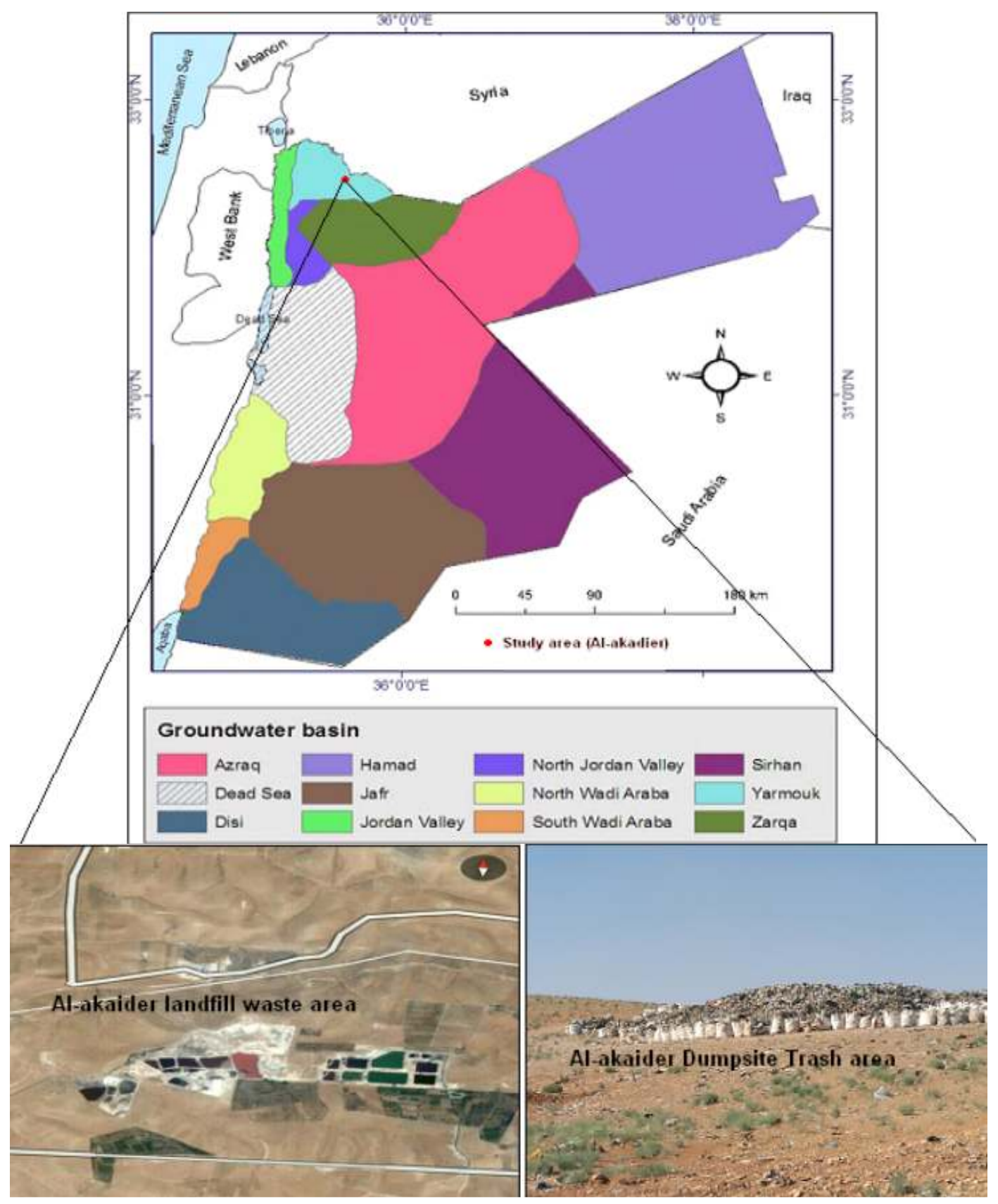

Fig. 1: The main surface water Basins in Jordan shows study area (Al-Akaider) within Yarmouk Basin 
natural sources are related to the rock formation or anthropogenic sources, including the direct application of fertilizers and pesticides, or irrigation by using wastewater treatment plant and human consumption activity (influent wastewater treatment plant, treated or untreated wastewater).

\section{MATERIALS AND METHODS}

Study area: The study area (Al-akaider) is located on the east side of the Yarmouk Basin, in the northern part of Jordan. $75 \%$ of this basin lies in Syria. In Jordan, the basin is located between the coordinates $36^{\circ} 0^{\prime} 30^{\prime \prime}$ to $36^{\circ} 11^{\prime} 0^{\prime \prime} \mathrm{E}$ and $32^{\circ} 20^{\prime} 210^{\prime \prime}$ to $32^{\circ} 30^{\prime} 240^{\prime \prime} \mathrm{N}$ (Fig. 1), covering an area of about $1,426 \mathrm{~km}^{2}$, (MWI, 2012). The adjacent mountainous areas and heights, which stand at $1,200 \mathrm{~m}$ above sea level, are the highest uplands to the east of the Jordan Rift Valley. The Yarmouk River flows on the borders between Syria and Jordan, which delineates the northern boundary of the study area, where as the Jordan River represents the western boundary. The Yarmouk River originates from Jabel Al-Arab in Syria and drains from the Jordanian and Syrian territories. The Al-Wehda Dam was constructed in 2006 between Jordan and Syria across this river. The dam supplies Jordan with about 110 $\mathrm{MCM} / \mathrm{yr}$ of potable water. The water quality of the springs discharging into the dam is of great importance for determining the usability of the stored waters. The Yarmouk River Basin is highly recharged by rainfall and having good water quality. It is also the main supplier of domestic and irrigation water for Irbid, northern Jordan Valley and Amman. The groundwater quality of the Yarmouk basin reflects the land uses within and beyond the basin area, the former is still restricted to rain foiled and some irrigated agriculture (Al-Taaniet al., 2012; Batayneh, 2010).

Geological setting: The study area is covered by middle to upper cretaceous rocks and Lower Tertiary limestone,marlto bituminousmarl, clay marl and dolomite rocks for Ajlune and Belqa Group formations (Basem, 1996). Quaternary gravels overlie the cretaceous and Tertiary beds. The description of each geological unit's area is listed in Table 1 and Fig. 2. The formation is exposed in the central to northern part of the basin. Basalt rocks outcrops in the western part of the study area covering Huwwara, Duneiba and west of Um Qeis area. The basalt erupted from Joulan Heights before formation of the drainage system and extended to hart Irbid basalt (Al-Malabeh, 2015). It consists of the eastern part of the outcrop, basalt cavers South of El-Mukheiba and west of El-Himmah area.

Hydrogeology: The hydrogeology of the study area covers the upper aquifer in the northwestern part of Jordan, located within the yarmouk basin (Fig. 1). The landfill positioned above the layers of Umm Rijam (B4) formation with high permeability, below the ALMuwaqqar formation (B3) with impermeable layers and a thickness ranging between $120-300 \mathrm{~m}$, forms a shallow aquifer that has a depth of almost $220 \mathrm{~m}$ (Table $2)$. The discharging wells in the area released from shallow aquifer of Wadi Es-Sir formation (A7) and Amman silicified limestone formation (B2). The depth of the water level is about $220 \mathrm{~m}$ below the ground surface and the groundwater movement in the basin is from northeast towards the west (through under the landfill area) Grammar Jordan Valley (El-Naser, 1991). The groundwater flow is controlled by two major faults that cut across the basin part of the flow, which is generally northward towards the Yarmouk River and the other part is westward towards the Jordan River. The Yarmouk River and groundwater are the primary sources of freshwater in the basin, with $65 \%$ of groundwater used for irrigation and domestic purposes (JISM (Jordanian Institution for Standards and Metrology), 2008). The two formations within the Yarmouk basin forming a deep confined aquifer are kurnub sandstone and Amman Wadi Es-Sir formation(El-Naser, 1991).

Table 1: Geological classification of rock units in the study area

\begin{tabular}{|c|c|c|c|c|c|c|}
\hline Era & Period & Epoch & Stage & Group & Formation & Description \\
\hline Cenozoic & Quaternary & Recent & Holocene & Plateau & Alluvium & Soil, sand and gravel \\
\hline \multirow[t]{8}{*}{ Mesozoic } & Cretaceous & Upper & Pleistocene & Belqa & Basalt & Basalt,clay \\
\hline & & & & & $\begin{array}{l}\text { Umm Rijam (URC) } \\
\text { B4 }\end{array}$ & Chert-Limestone \\
\hline & & & Maestrichtian & & $\begin{array}{l}\text { Muwaqqar (MCM) } \\
\text { B3 }\end{array}$ & $\begin{array}{l}\text { Chalk,marl and chalky } \\
\text { limestone }\end{array}$ \\
\hline & & & Campanian & & Amman (ASL) B2 & $\begin{array}{l}\text { Chert, limestone with } \\
\text { phosphates }\end{array}$ \\
\hline & & & Santonian & & $\begin{array}{l}\text { Umm Ghudran } \\
\text { (WG) B1 }\end{array}$ & $\begin{array}{l}\text { Chalk, marl and marly } \\
\text { limestone }\end{array}$ \\
\hline & & Middle & Turonian & Ajlun (A1/A6) & $\begin{array}{l}\text { Wadi Es-Sir (WSL) } \\
\text { A7 }\end{array}$ & $\begin{array}{l}\text { Hard crystalline } \\
\text { limestone. Dolomite }\end{array}$ \\
\hline & & & Cenomanian & & Shueib & $\begin{array}{l}\text { Light grey limestone. } \\
\text { interbedded with marls } \\
\text { and marly limestone }\end{array}$ \\
\hline & & & & & Hummar & $\begin{array}{l}\text { Hard dense limestone and } \\
\text { dolomite limestone }\end{array}$ \\
\hline
\end{tabular}




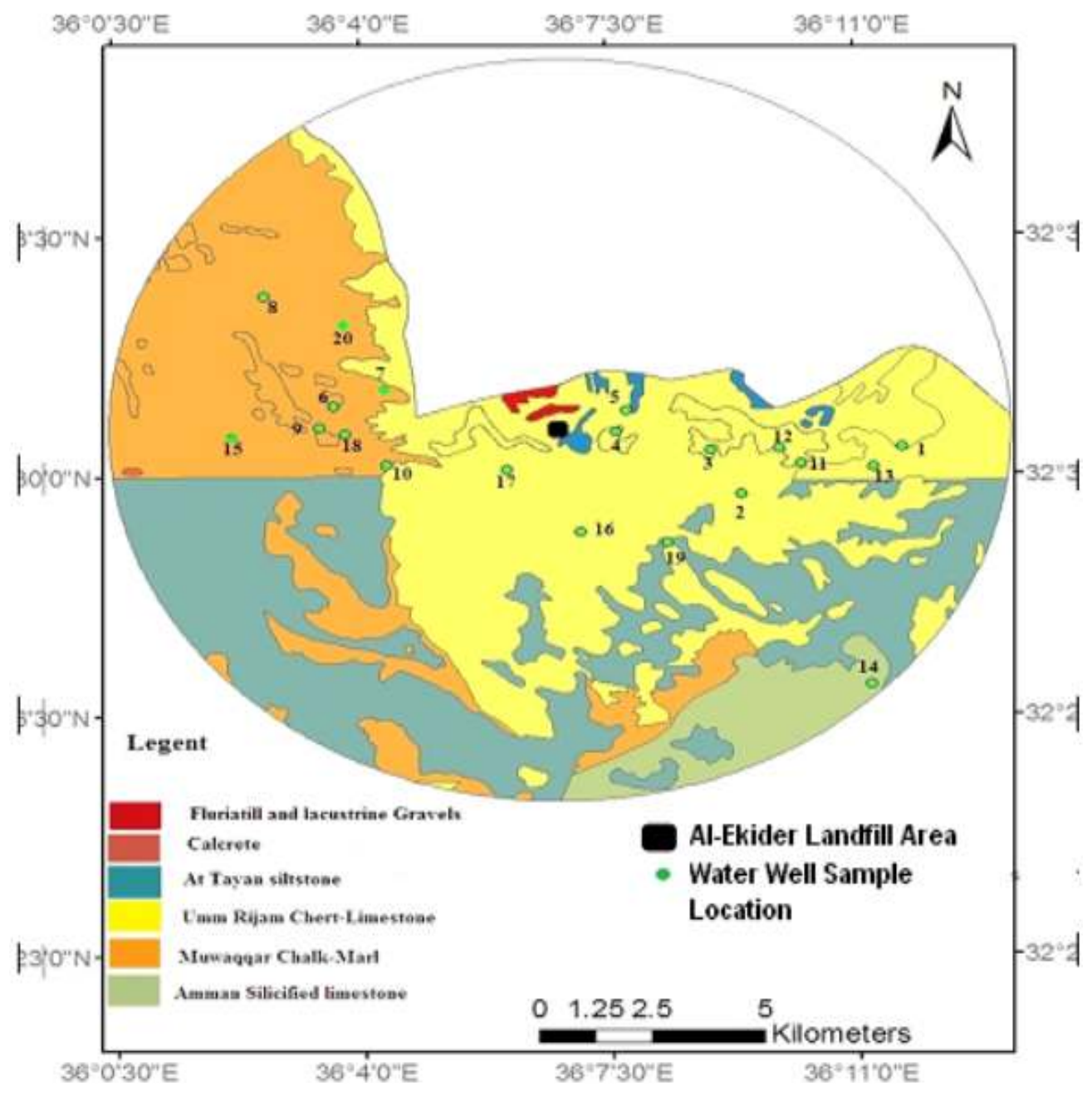

Fig. 2: Geological and water well sample location map of the study area

Table 2: The geological strata thickness in the region and shows the aquifers covering the study area (after JISM (Jordanian Institution for Standards and Metrology, 2008)

\begin{tabular}{|c|c|c|c|}
\hline Hydrogeological unit & Thickness (m) & Aquifer classification & Lithological description \\
\hline$\overline{\mathrm{B} 4}$ & A few meters & Aquifer & Limestone consists of chalks, limestone cherts. \\
\hline B3 & $>300 \mathrm{~m}$ & Aquitard & Low Permeable consists of marl and marl limestone. \\
\hline $\mathrm{B} 1 / 2$ & Around $200 \mathrm{~m}$ & Good Aquifer & $\begin{array}{l}\text { Massive limestone consists of chalks, limestone cherts and } \\
\text { phosphatic beds. }\end{array}$ \\
\hline A7 & $200-300 \mathrm{~m}$ & Good Aquifer & $\begin{array}{l}\text { Consists of white to light grey semi-crystalline limestone, Dolomatic } \\
\text { limestone and becomes more chalky to the base of the unit. }\end{array}$ \\
\hline A5/6 & $100-150 \mathrm{~m}$ & Aquitard & $\begin{array}{l}\text { Low Permeable dominated by Yellowish marl with intercalations of } \\
\text { limestone, dolomite, and shale. }\end{array}$ \\
\hline
\end{tabular}

Sampling and analytical techniques: Twenty-one water samples have been collected from groundwater wells in the surrounding areas of Al-akaiderlandfill positioned within the Yarmouk Basin (Fig. 2). The water samples were collected in $1 \mathrm{~L}$ polyethylene bottles and $1.5 \mathrm{~mL}$ of $1 \mathrm{~N} \mathrm{HNO}_{3}$ (preservation of sample) has been added. The chemical analyses of the samples were done in Water, Environment and Arid Regions Research Center in Al al-Bayt University, for heavy metals ( $\mathrm{Zn}, \mathrm{Cu}, \mathrm{Mn}, \mathrm{Pb}, \mathrm{Cd}$ and $\mathrm{Fe}$ ) using Atomic Absorption Spectrophotometer (AAS). The PH, Electrical Conductivity (EC) and Total Dissolved
Solids (TDS) were measured in the field. The results are listed in Table 3.

\section{RESULTS AND DISCUSSION}

Results: The chemical concentrations of the heavy metals for the study area are listed in Table 3. The chemical characteristics for the heavy metals are as follows:

Zinc $\left(\mathbf{Z n}^{+\mathbf{2}}\right)$ : Zinc is an essential element found in surface water and groundwater levels that usually do 
Res. J. Environ. Earth Sci.,10(1): 16-23, 2018

Table 3: Chemical analysis (mg/l) of the water well samples study

\begin{tabular}{llllllllll}
\hline S. No. & $\mathrm{Zn}(\mathrm{mg} / \mathrm{L})$ & $\mathrm{Cu}(\mathrm{mg} / \mathrm{L})$ & $\mathrm{Mn}(\mathrm{mg} / \mathrm{L})$ & $\mathrm{Pb}(\mathrm{mg} / \mathrm{L})$ & $\mathrm{Cd}(\mathrm{mg} / \mathrm{L})$ & $\mathrm{Fe}(\mathrm{mg} / \mathrm{L})$ & $\mathrm{PH}$ & $\mathrm{EC} \mu \mathrm{s} / \mathrm{Cm}$ & $\mathrm{TDS} \mathrm{mg} / \mathrm{L}$ \\
\hline T1 & 0.089 & 0.021 & 0.022 & 0.135 & 0.008 & 0.184 & 7.01 & 921 & 575.62 \\
T2 & 0.175 & 0.019 & 0.012 & 0.153 & 0.011 & 0.46 & 7.20 & 892 & 557.52 \\
T3 & 0.057 & 0.001 & 0.023 & 0.126 & 0.007 & 0.133 & 6.69 & 830 & 518.75 \\
T4 & 0.075 & 0.002 & 0.011 & 0.152 & 0.012 & 0.055 & 6.89 & 989 & 618.12 \\
T5 & 0.102 & 0.056 & 0.017 & 0.199 & 0.011 & 0.027 & 7.36 & 784 & 490.21 \\
T6 & 0.159 & 0.044 & 0.013 & 0.188 & 0.013 & 0.016 & 6.67 & 1359 & 849.37 \\
T7 & 0.082 & 0.002 & 0.018 & 0.191 & 0.014 & 0.162 & 6.81 & 939 & 586.87 \\
T8 & 0.119 & 0.039 & 0.026 & 0.232 & 0.011 & 0.371 & 6.81 & 986 & 616.25 \\
T9 & 0.096 & 0.078 & 0.011 & 0.189 & 0.011 & 0.609 & 7.06 & 882 & 551.25 \\
T10 & 0.127 & 0.079 & 0.005 & 0.184 & 0.012 & 1.179 & 7.15 & 739 & 461.87 \\
T11 & 0.069 & 0.048 & 0.018 & 0.177 & 0.010 & 0.192 & 7.74 & 906 & 566.25 \\
T12 & 0.072 & 0.006 & 0.012 & 0.214 & 0.012 & 0.135 & 8.04 & 759 & 474.37 \\
T13 & 0.049 & 0.07 & 0.009 & 0.203 & 0.011 & 0.002 & 7.13 & 966 & 303.75 \\
T14 & 0.169 & 0.047 & 0.015 & 0.214 & 0.013 & 0.003 & 8.43 & 770 & 481.25 \\
T15 & 0.089 & 0.022 & 0.008 & 0.242 & 0.011 & 0.064 & 7.72 & 804 & 502.52 \\
T16 & 0.059 & 0.041 & 0.009 & 0.210 & 0.014 & 0.052 & 7.68 & 870 & 543.75 \\
T17 & 0.083 & 0.051 & 0.011 & 0.222 & 0.012 & 0.059 & 7.75 & 970 & 606.25 \\
T18 & 0.08 & 0.051 & 0.023 & 0.224 & 0.013 & 0.003 & 7.39 & 1074 & 671.25 \\
T19 & 0.05 & 0.034 & 0.003 & 0.207 & 0.015 & 0.171 & 7.55 & 876 & 547.52 \\
T20 & 0.081 & 0.04 & 0.005 & 0.229 & 0.016 & 0.206 & 7.28 & 1089 & 680.62 \\
T21 & 0.072 & 0.011 & 0.005 & 0.227 & 0.015 & 0.201 & 7.31 & 957 & 598.13 \\
Max. & 0.175 & 0.079 & 0.005 & 0.126 & 0.007 & 1.179 & 8.43 & 1359 & 849.37 \\
Min. & 0.049 & 0.056 & 0.026 & 0.242 & 0.016 & 0.064 & 6.67 & 739 & 303.75 \\
\hline
\end{tabular}

not exceed 0.01-0.05 $\mathrm{mg} / \mathrm{L}$ (World Health Organization, 2003a). If the concentration of zinc in drinking water increases, the taste gripping becomes undesirable and the water containing a concentration of zinc looks more than $5 \mathrm{mg} / \mathrm{L}$, turbid and forms a thin layer of fatty shape when boiling (World Health Organization, 2003a). The zinc ion concentration in drinking water that has been water samples collected from the wells ranged between $0.175-0.049 \mathrm{mg} / \mathrm{L}$. The zinc concentration in the study samples of all wells lies within the Jordanian specifications for drinking water, which the Jordanian Institution for Standards and Metrology identifies (JISM (Jordanian Institution for Standards and Metrology), 2008). The upper limit for the concentration of zinc in drinking water equals 4.0 $\mathrm{mg} / \mathrm{L}$.

Copper $\left(\mathbf{C u}^{+2}\right)$ : The ion copper in drinking water has very low concentrations of up to a few micrograms per liter. The sources of copper in the water and air dust fumes from chimneys constitute $0.4 \%$ of the copper sources in nature (Pettersson and Rasmussen, 1999; Stenhammar, 1999). Some studies have reached the signs of fears of the possibility of a relationship for copper in drinking water, diseases, cirrhosis in early childhood when the children are fed by bottles. The focus of copper is 1-2 $\mathrm{mg} / \mathrm{L}$ in drinking water and includes healthy limits for the safety of children. The event of increased copper ion concentration in drinking water for $5 \mathrm{mg} / \mathrm{L}$ gives color and unpleasantly bitter taste of water (World Health Organization, 2003b). Upon analysis of the samples, it was shown that concentrations of copper ranged between 0.056-0.079 $\mathrm{mg} / \mathrm{L}$. The concentration of the $\mathrm{Cu}$ ion lies within the limit of the Jordanian Institution for Standards and Metrology (JISM (Jordanian Institution for Standards and Metrology), 2008), which is $1.0 \mathrm{mg} / \mathrm{L}$ and indicates that there is no contamination in the water.

Manganese (Mn): The concentration of manganese ion for the sample study ranges from $0.005-0.026 \mathrm{mg} / \mathrm{L}$. This is the focus within the limit allowed by the Jordanian Institution for Standards and Metrology for the concentration $(0.1 \mathrm{mg} / \mathrm{L})$ in Drinking Water (JISM (Jordanian Institution for Standards and Metrology), 2008).

Lead $\left(\mathbf{P b}^{+\mathbf{2}}\right)$ : The primary sources of lead ion in water are motor vehicle exhaust and industrial solid, gaseous and liquid wastes. Lead is a toxic effect on the human body, where the longer infants, children and pregnant women are more layered in preparation for adverse health effects of lead (World Health Organization, 2003c). The lead concentration in the studied samples ranges between 0.126 and $0.242 \mathrm{mg} / \mathrm{L}$. It appears to exist and was identical to the Jordanian Institution for Standards and Metrology limit for the concentration of lead $(0.01 \mathrm{mg} / \mathrm{L})(\mathrm{JISM}$ (Jordanian Institution for Standards and Metrology), 2008).

Cadmium (Cd): Cadmium compounds are widely used in industrial batteries. The water distribution networks are used in galvanized pipes and welding. The sources of cadmium contamination are artificial fertilizers (World Health Organization, 2003d). The chemical analysis of studied samples shows that the ion concentration of cadmium in all wells ranges between 0.007 and $0.016 \mathrm{mg} / \mathrm{L}$ (Table 3). It appears to be within the range of the Jordan Specifications for drinking water $(0.1 \mathrm{mg} / \mathrm{L})$ and Jordanian Institution for Standards and Metrology $(0.003 \mathrm{mg} / \mathrm{L})(J o r d a n i a n$ Institution for Standards and Metrology, 2008). 


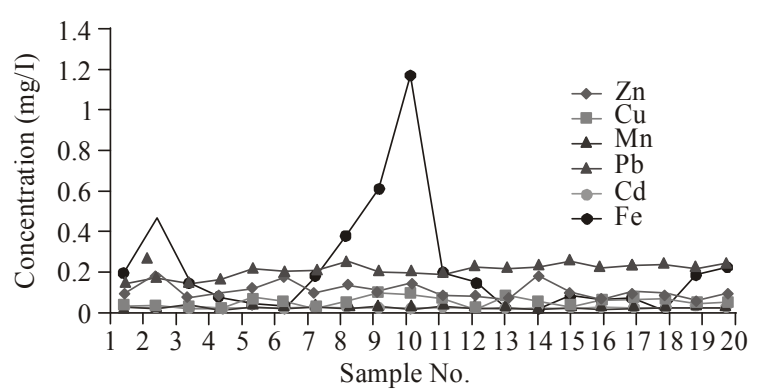

Fig. 3: Distribution of heavy metal concentration (mg/l) of the sample study

Iron $\left(\mathrm{Fe}^{+2}\right.$ and $\left.\mathrm{Fe}^{+3}\right)$ : There are no iron ions in the groundwater anaerobic shaped ferrous iron $\mathrm{Fe}^{+2}$ and a concentration of up to several milligrams per liter, without a change in color or turbidity in the water. While the pumping from the wells directly as volcanic rocks were the source of iron (World Health Organization, 2003e). The performance of the necessary tests shows that the rising concentration of iron for the well T10 $(1.179 \mathrm{mg} / \mathrm{L})$ was higher than the allowable limit, which is defined by the Jordanian Institution for Standards and Metrology $(1.0 \mathrm{mg} / \mathrm{L})$ of drinking water (JISM (Jordanian Institution for Standards and Metrology), 2008). The iron concentration in well T10 $(1.179 \mathrm{mg} / \mathrm{L})$ located away from the west landfill area is about $4 \mathrm{~km}$. The contamination in this well (T10) is an indication of natural sources, which mixes deep water with deep aquifer. The deep aquifers are composed of two formations; Amman WadiEs-Sir and kurnub sandstone, with highly iron oxide. This formation reflects to increase the percentage of iron ions for the groundwater.

\section{DISCSSION}

The concentrations of $\mathrm{Zn}, \mathrm{Cu}, \mathrm{Mn}, \mathrm{Pb}$ and $\mathrm{Cd}$ in all the water samples have been within the maximum permissible limits of Jordanian Drinking Water. The concentrations of the zinc and iron elements considered below EPA (2005)level are not toxic in drinking water. Copper is classified as a priority pollutant because of its adverse health effects (Borah et al., 2009). Lead is not an essential trace element; it is the concentration in the organism and has no known biological function. It can cause a variety of harmful health effects (Botkin and Keller, 2005) and is known as a fatal neurotoxicity (Thomson and Parry, 2006). If excessive concentrations of cobalt can cause death and various compounds of nickel are carcinogenic (Dunnick et al., 1995), thencadmium and manganese concentrations lies within the range of Jordan Specifications for drinking water and within Jordanian Institution for Standards and Metrology. These menaces provoke the studies on the monitoring of these heavy metals in this chain to be important for the protection of public health.
The result of the iron concentration shows (Fig. 3)that all the well samples within the Jordanian Institution for Standards and Metrology (2008) (1.00 $\mathrm{mg} / \mathrm{L}$ ) expects well sample number T10 to have high concentrations $(1.179 \mathrm{mg} / \mathrm{L})$, exceeding the Jordanian Institution for Standards and Metrology (2008). This well (T10) is located about $4 \mathrm{~km}$ west of the landfill area and within an impermeable surface formation (Muwqqar Chalk Marl (B3)). Explaining increasing concentrations of $\mathrm{Fe}$ is by mixing water between shallow and deep aquifers, since the deep aquifer consists of sandstone with highly iron oxide. The $\mathrm{pH}$ value for all the studied samples ranges from 6.67 to 8.43 , which has an average of 7.60. This result, documented within the Jordanian Institution for Standards and Metrology (2008), ranges from 6.5 to 8.5. The TDS value in the samples from 849 to 303 $\mathrm{mg} / \mathrm{L}$ with an average of $576 \mathrm{mg} / \mathrm{L}$, is documented within Jordanian Institution for Standards and Metrology (2008) $(1000 \mathrm{mg} / \mathrm{L})$. The apparent conclusion is that the concentrations of $\mathrm{Zn}, \mathrm{Cu}, \mathrm{Mn}, \mathrm{Pb}$ and $\mathrm{Cd}$ in all the water samples have been within the maximum permissible limits of Jordan Drinking Water. This study explains that groundwater does not pollute heavy metals and is not affected by Al-akaider landfill to the seepage of groundwater around the study area within the Yarmouk basin.

\section{CONCLUSION}

The results of the study concentration of the heavy metal in the groundwater around Al-akaider landfill waste area appear as follows:

- The zinc concentration $(0.175-0.049 \mathrm{mg} / \mathrm{L})$ in the study samples of all wells lies within the Jordanian specifications for drinking water (Jordanian Institution for Standards and Metrology, 2008).

- The concentration of the $\mathrm{Cu}$ ion (0.056-0.079 $\mathrm{mg} / \mathrm{L}$ ) lies within the limit of the Jordanian Institution for Standards and Metrology (Jordanian Institution for Standards and Metrology, 2008).

- The lead concentration in the studied samples ranges between 0.126 and $0.242 \mathrm{mg} / \mathrm{L}$. It seems to exist and was identical to the Jordanian Institution for Standards and Metrology limit for the concentration of lead $(0.01 \mathrm{mg} / \mathrm{L})$.

- Cadmium and manganese concentrations between $(0.007$ to $0.016 \mathrm{mg} / \mathrm{L})$ and $(0.005-0.026 \mathrm{mg} / \mathrm{L})$ lies within the range of Jordan Specifications for drinking water and within Jordanian Institution for Standards and Metrology (2008).

- The result of the iron concentration shows all the well samples within the Jordanian Institution for Standards and Metrology, 2008 (1.00 mg/L). It is expected that well sample number T10 has high concentrations $(1.179 \mathrm{mg} / \mathrm{L})$ exceeding the Jordanian Institution for Standards and Metrology 
(2008). This well (T10) is located about $4 \mathrm{~km}$ west of the landfill area and within the impermeable surface formation (Muwqqar Chalk Marl (B3). Explaining increasing concentrations of $\mathrm{Fe}$ is by mixing water between shallow and deep aquifers, since the deep aquifer consists of sandstone with highly iron oxide.

- $\quad$ The concentrations of $\mathrm{Zn}, \mathrm{Cu}, \mathrm{Mn}, \mathrm{Pb}, \mathrm{Cd}$ and $\mathrm{Fe}$ in all the water samples have been within the maximum permissible limits of Jordanian Drinking Water. This study explains that the groundwater is not the pollution of heavy metals and that no affected Al-akaider landfill seeped into the groundwater around the study area within Yarmouk basin.

\section{ACKNOWLEDGEMENT}

The authors represent their great thanks to Water, Environment and Arid Regions Research Centre, at Al al-Bayt University for analysis of the heavy metals $\mathrm{Zn}$, $\mathrm{Cu}, \mathrm{Mn}, \mathrm{Pb}, \mathrm{Cd}$ and $\mathrm{Fe}$ by using Atomic Absorption Spectrophotometer (AAS). The authors are also grateful to chemist WedadKhader for her help to measure $\mathrm{PH}$, EC and TDS at Institute of Earth and Environmental Sciences lab, Al-al-Bayt University.

\section{REFERENCES}

Abu-Jaber, N. and A. Kharabsheh, 2008.Groundwater origin and movement in the upper Yarmouk Basin, Northern Jordan. Environ. Geol.,54(7): 1355-1365.

Al-Malabeh, A., 2015. Geological Location map of Basalt flows in north Jordan. Department of the Earth and Environmental Sciences, Yarmouk University, Irbid Jordan.

Al-Taani, A.A., A.T. Batayneh, N. El-Radaideh, I. AlMomani and A. Rawabdeh, 2012.Monitoring of selenium concentrations in major springs of Yarmouk Basin, North Jordan. World Appl. Sci. J., 18(5): 704-714.

Basem, K., 1996. The geology of Irbid, Map Sheet No. 3255 II. Natural Resources Authority, Geological Mapping Division.

Batayneh, A.T., 2010. Heavy metals in water springs of the Yarmouk Basin, North Jordan and their potentiality in health risk assessment. Int. J. Phys. Sci., 5(7): 997-1003.

Borah, K.K., B. Bhuyan and H.P. Sarma, 2009.Heavy metal contamination of groundwater in the tea garden belt of Darrang district, Assam, India.E-J. Chem., 6(S1): S501-S507.

Botkin, B.D. and E.A. Keller, 2005. Environmental Science: Earth as a Living Planet. Wiley, New York.

Denny, E., K. Donnelly, R. McKay, G. Ponte and T. Uetake, 2008.Sustainable Water Strategies for Jordan. International Economic Development Program, Gerald R. Ford School of Public Policy, University of Michigan, Ann Arbor.
Dunnick, J.K., M.R. Elwell, A.E Radovsky, J.M. Benson, F.F. Hahn, K.J. Nikula, E.B. Barr and C.H. Hobbs, 1995. Comparative carcinogenic effects of nickel subsulfide, nickel oxide, or nickel sulfate hexahydrate chronic exposures in the lung. Cancer Res., 55: 5251-5256.

El-Naser, H., 1991.Groundwater resources of the deep aquifer system in NW Jordan-hydrogeological and hydrochemicalquasi 3-dimensional modeling. Ph.D. Thesis, University of Wurzburg, Germany, pp: 144.

EPA, 2005.Toxicological Review of Zinc and Compounds. U.S. Environmental Protection Agency, Open URL, Washington D.C.

Forstner, U., 1990. Contaminated sediments. Lecture Notes in Earth Science, Springer-Verlag, Berlin, Vol. 21.

Ghasemi, M., A.R. Keshtkar, R. Dabbagh and S. JaberSafdari, 2011. Biosorption of uranium in a continuous flow packed bed column using Cystoseiraindica biomass.Iran J. Environ. Health Sci. Eng., 8(1): 65-74.

Ghrefat, H. and N. Yusuf, 2006.Assessing $\mathrm{Mn}, \mathrm{Fe}, \mathrm{Cu}$, $\mathrm{Zn}$ and $\mathrm{Cd}$ pollution in bottom sediments of Wadi Al-Arab Dam, Jordan. Chemosphere, 65(11): 2114-2121.

Harte, J., C. Holdren, R. Schneider and C. Shirley, 1991.Toxics A to Z, A Guide to Everyday Pollution Hazards.University of California Press, Oxford, England.

JISM (Jordanian Institution for Standards and Metrology), 2008.Technical Regulation.WaterDrinking Water.Jordanian Institution for Standards and Metrology, Hashemite Kingdom of Jordan.

Khodabakhshi, A., M. Amin and M. Mozaffari, 2001.Synthesis of magnetic nanoparticles and evaluation efficiency for arsenic removal from simulated industrial wastewater. Iran J. Environ. Health Sci. Eng., 8: 189-200.

MacFarlane, G.R. and M.D. Burchett, 2000.Cellular distribution of copper, lead and zincin the grey mangrove,Avicennia marina (Forsk.) vierh.Aquat. Bot., 68: 45-59.

Marcovecchio, J.E., S.E. Botte and R.H. Freije, 2007. Heavy Metals, Major Metals, Trace Elements. In: Nollet, L.M., (Ed.), Handbook of Water Analysis. 2nd Edn., CRC Press, London.

MWI (Ministry of Water and Irrigation), 2012. Jordan Institution for Standards and Metrology: Drinking Water Standard JS 286:2008. 5th Edn., in Arabic, Retrieved on May 2.

Nortcliff, S., G. Carr, R.B. Potter and K. Darmame, 2008. Jordan's Water Resources: Challenges for the Future. Geographical Paper No. 185, The University of Reading, United Kingdom.

Obeidat, M.M., F.Y. Ahmad, N.A. Hamouri, A.M. Massadeh and F.S. Athamneh, 2008. Assessment of Nitrate contamination of Karst springs, BaniKanana, Northern Jordan. Rev. Mex.Cienc. Geol., 25(3): 426-437. 
Öztürk, M., G. Özözen, O. Minareci and E. Minareci, 2009.Determination of heavy metals in fish, water and sediments of Avsar Dam Lake in Turkey. Iran J. Environ. Health Sci. Eng., 6(2): 73-80.

Pettersson, R. and F. Rasmussen, 1999.Daily intake of copper from drinking water among young children in Sweden. Environ. Health Perspect., 107: 441446.

Schuurmann, G. and B. Market, 1998.Ectotoxicology: Ecological Fundamentals, Chemical Exposure, and Biological Effects. John Wiley and Sons Inc and SpektrumAkademischerVerlag.

Stenhammar, L., 1999. Diarrhoea following contamination of drinking water with copper. Eur. J. Med. Res., 4: 217-218.

Thomson, R.M. and G.J. Parry, 2006. Neuropathies associated with excessive exposure to lead. Muscle Nerve, 33: 732-741.

Underwood, E.J., 1956. Trace Elements in Humans and Animals Nutrition. 3rd Edn., Academic Press, New York.

Vodela, J.K., J.A. Renden, S.D. Lenz, W.H. McElhenneyand B.W. Kemppainen, 1997.Drinking water contaminants (Arsenic, cadmium, lead, benzene, and trichloroethylene). 1. Interaction of contaminants with nutritional status on general performance and immune function in broiler chickens.Poult. Sci., 76: 1474-1492.
World Health Organization (WHO), 2003a. "Zinc in Drinking-water" Background Document for Preparation of WHO Guidelines for Drinkingwater Quality. World Health Organization, Geneva, (WHO/SDE/WSH/03.04/17).

World Health Organization (WHO), 2003b. "Copper in Drinking-water" Background Document for Preparation of WHO Guidelines for Drinkingwater Quality. World Health Organization Geneva, (WHO/SDE/WSH/03.04/18).

World Health Organization (WHO), 2003c. "Lead in Drinking-water" Background Document for Preparation of WHO Guidelines for Drinkingwater Quality. World Health Organization, Geneva, (WHO/SDE/WSH/03.04/9).

World Health Organization (WHO), 2003d. "Cadmium in Drinking-water" Background Document for Preparation of WHO Guidelines for Drinkingwater Quality. World Health Organization, Geneva, (WHO/SDE/WSH/03.04/80).

World Health Organization (WHO), 2003e. "Iron in Drinking-water" Background Document for Preparation of WHO Guidelines for Drinkingwater Quality. World Health Organization, Geneva, (WHO/SDE/WSH/03.04/8). 